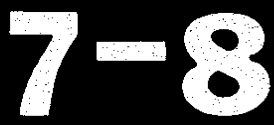




\section{Desk Copy}

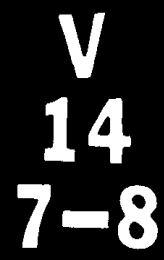

\section{OF LETTERS AND ENCYCLICALS}

James V. Schall, S.J.

\section{STILWELL \& THE VIETNAM EXPERIENCE \\ William Pfaff}

\section{ON OBLIGATION \& CIVIL DISOBEDIENCE}

\section{James F. Childress}

and more...

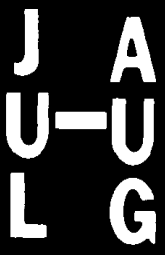

